\title{
Responses of Aphid Vectors of Potato leaf roll virus to Potato Varieties
}

\author{
Shaonpius Mondal, Department of Plant, Soil, and Entomological Sciences, University of Idaho, Aberdeen Research \& Extension Center, \\ Aberdeen, ID 83210; Erik J. Wenninger, ${ }^{\dagger}$ Department of Plant, Soil, and Entomological Sciences, University of Idaho, Kimberly Research \\ \& Extension Center, Kimberly, ID 83341-5082; Pamela J.S. Hutchinson, Department of Plant, Soil, and Entomological Sciences, University \\ of Idaho, Aberdeen Research \& Extension Center, Aberdeen, ID 83210; Jonathan L. Whitworth, USDA-ARS, Small Grains and Potato \\ Germplasm Research, Aberdeen, ID 83210; Deepak Shrestha, Department of Plant, Soil, and Entomological Sciences, University of Idaho, \\ Aberdeen Research \& Extension Center, Aberdeen, ID 83210; Sanford D. Eigenbrode and Nilsa A. Bosque-Pérez, Department of Plant, Soil, \\ and Entomological Sciences, University of Idaho, Moscow, ID 83844-2339; and William E. Snyder, Department of Entomology, Washington \\ State University, Pullman, WA 99164-6382
}

\begin{abstract}
Potato leaf roll virus (PLRV) can reduce tuber yield and quality in potato. Green peach aphid (Myzus persicae [Sulzer]) and potato aphid (Macrosiphum euphorbiae [Thomas]) are the two most important potato-colonizing PLRV vectors in the Pacific Northwest. We compared My. persicae and Ma. euphorbiae densities and PLRV incidences among potato varieties in the field to clarify the relationships between aphid abundance and PLRV incidence in plants. Aphids were sampled weekly over three years in the potato varieties Russet Burbank, Ranger Russet, and Russet Norkotah in a replicated field trial. In all years, My. persicae was more abundant than Ma. euphorbiae, representing at least $97 \%$ of samples. My. persicae densities did not differ among potato varieties across years; very low numbers of Ma. euphorbiae precluded such

statistical comparisons for this species. PLRV infection did not differ significantly among potato varieties, although the percent of PLRV-infected plants differed among years when all varieties were combined (46\% in $2013,29 \%$ in 2011, $13 \%$ in 2012). For Ranger Russet and Russet Norkotah, PLRV incidence was positively correlated with aphid abundance as well as proportion of PLRV-positive aphids. In Russet Burbank, only aphid abundance was positively correlated with PLRV infection. Our results suggest that the three most commonly grown potato varieties in our region do not differ in their susceptibility to PLRV infection, and that aphid density was a consistent indicator of the risk of infection by this virus across varieties. Both of these findings can be used to hone PLRV monitoring and modeling efforts.
\end{abstract}

Commercial and seed potato (Solanum tuberosum L.) production are constrained by several viral diseases that reduce yields and lower tuber quality (Ragsdale et al. 2001). Among the 28 viral species that infect potato, Potato leaf roll virus (PLRV, genus Polerovirus, family Luteoviridae) is one of the most important viruses known to cause potato yield loss worldwide (Salazar 1996). Typical PLRV symptoms include rolling of leaves, chlorosis, yellowing, stunting of infected plants, and tuber net necrosis in some potato varieties including Russet Burbank, the most widely grown potato variety in the U.S.A. (Alvarez and Srinivasan 2005; Douglas and Pavek 1972; Nault 1997). PLRV has a wide host range including plants from Solanaceae, Cricufereae, Nolanaceae, Amaranthaceae, Brassicaceae, Malvaceae, Portulacaceae, and Chenopodiaceae (Hanafi et al. 1989, 1995; Smith et al. 2012; Srinivasan and Alvarez 2008; Thomas 1993; Thomas and Hassan 2002).

PLRV is readily transmitted by several potato-colonizing aphid species in a persistent, circulative, and nonpropagative manner (Harrison 1958; Nault 1997; Radcliffe and Ragsdale 2002; Robert and Bourdin 2001; Syller 1996). Green peach aphid (Myzus persicae Sulzer) and potato aphid (Macrosiphum euphorbiae Thomas) are the two main potato-colonizing aphid vectors of PLRV in the Pacific Northwest U.S.A. (Radcliffe and Ragsdale 2002; Ragsdale et al. 2001). My. persicae, which is economically the most important vector of PLRV (Halbert et al. 1995; Radcliffe and Ragsdale 2002;

Current address of S. Mondal: 334 Plant Science Building, Plant Pathology and Plant-Microbe Biology Section, School of Integrative Plant Science, Cornell University, Ithaca, NY 14853-5904. Current address of D. Shrestha: Department of Entomology and Nematology, University of Florida, Gainesville, FL 32611.

${ }^{\dagger}$ Corresponding author. E-mail: erikw@uidaho.edu

Accepted for publication 4 June 2017.

@ 2017 The American Phytopathological Society
Ragsdale et al. 2001), transmits PLRV more efficiently than Ma. euphorbiae (Tamada et al. 1984; Woodford et al. 1995).

Russet Burbank, Russet Norkotah, and Ranger Russet are widely grown potato varieties in seven major potato-growing states of the U.S.A., with $39.7,13.1$, and $9.9 \%$ of the total potato acreage, respectively. In Idaho, these three potato varieties represent 53, 21, and 14\% of the potato acreage, respectively (NASS 2013). Potato varieties other than those considered here are known to vary in their susceptibility to PLRV depending on their levels of resistance toward PLRV infection and aphid colonization (Corsini et al. 1994; DiFonzo et al. 1994). My. persicae and Ma. euphorbiae colonization can differ among potato varieties, although patterns may change from year to year depending on frequency of insecticide use, prevalence of natural enemies, and weather parameters (Davis et al. 2007; Flis et al. 2005). However, Russet Burbank, Russet Norkotah, and Ranger Russet have not been evaluated with respect to their susceptibility to colonization by My. persicae and Ma. euphorbiae, or for their differences in susceptibility to PLRV infection (Corsini and Brown 2001; Corsini et al. 1994).

During the early 1990s, PLRV incidence increased across the major potato-growing regions of the U.S.A., including the Northern Great Plains and the Columbia Basin in Washington State, possibly due to greater abundance and movement of aphid vectors in these areas (Ragsdale et al. 2001). Environmental factors including lowlevel jet streams and high and fluctuating temperatures might have contributed to this increase in aphid vector movement, particularly influencing the spring aphid migration that facilitates the initial vectoring of PLRV to potato fields (Davis et al. 2006; Thomas et al. 1997; Zhu et al. 2006). Virus incidence also could have been enhanced by increasing prevalence of alternative weed hosts, and the presence of invasive weed species that could promote the field spread of PLRV (Davis and Radcliffe 2008; Hutchinson 2014; Srinivasan et al. 2013; Thomas 1993).

Management of aphid vectors of PLRV is challenging because of their reproductive potential, diverse host range, and tendency to develop resistance to insecticides. A common management approach is prophylactic use of systemic and contact insecticides, which 
suppresses aphids effectively, but does not always adequately reduce the incidence of PLRV (DiFonzo et al.1995; Mowry 2001, 2005; Ragsdale et al. 2001). This is in part because aphids remain viruliferous throughout their lives after PLRV acquisition (Radcliffe and Ragsdale 2002) so that small populations can still cause substantial spread of virus. Furthermore, prophylactic use of insecticides is costly, negatively affects beneficial arthropods, and can select for insecticide resistance (Foster et al. 2008; van Toor et al. 2008). Indeed, the recent development of resistance by My. persicae to neonicotinoid insecticides underscores the need for improved integrated pest management strategies for the aphid complex responsible for PLRV transmission (Bass et al. 2011, 2014; Foster et al. 2000; Fray et al. 2014; Nauen and Denholm 2005; Puinean et al. 2010).

Although PLRV inoculum has been reduced in the potato production areas of the Pacific Northwest due at least in part to the use of virus-free seed tubers (R. Davidson, personal communication), virus inoculum levels in regional aphid and in alternative-host weed populations are unpredictable from year to year. A better understanding of the phenology and population dynamics of aphid vectors on widely grown potato varieties will aid in assessing variety-specific risk to aphid infestation and PLRV infection. The aims of the present study were (1) to compare My. persicae and Ma. euphorbiae densities and PLRV incidences among three widely grown potato varieties under field conditions typical of Idaho, and (2) to assess relationships between aphid abundance (total and PLRV-positive) and PLRV prevalence within and among potato varieties.

\section{Materials and Methods}

Planting, cultivation, and plot layout. Field plots were located at the University of Idaho Kimberly Research and Extension Center near Kimberly, Idaho, U.S.A., during 2011, 2012, and 2013. In all three years, research plots were located adjacent to other field studies in which plants were inoculated with PLRV, and where PLRVnegative green peach aphids were released. To establish plots, seed tubers of Russet Burbank, Russet Norkotah, and Ranger Russet potato varieties were hand cut to seed pieces of ca. $70 \mathrm{~g}$. Prior to planting, seed pieces were treated with P.S.T. Plus Bark (J.R. Simplot Company, Boise, ID), which is composed of the fungicide Mancozeb (ethylene bisdithiocarbamate) and the micronutrients $\mathrm{Mn}$ and $\mathrm{Zn}$, at a rate of $10 \mathrm{~g}$ product per $\mathrm{kg}$ potato tuber seed. Each plot was planted during the last week of April each year, with one of the three varieties in each plot, using approximate spacings of $30.5 \mathrm{~cm}$ within rows and $91.5 \mathrm{~cm}$ between rows at a rate of $2.3 \mathrm{t} / \mathrm{ha}$ (ca. 33,300 seed pieces/ha). Standard agronomic practices developed by the University of Idaho were followed for fertility, irrigation, and weed management (Stark and Love 2003). Each year, plots were three rows wide by $7.6 \mathrm{~m}$ long, with eight replicate plots of each potato variety arranged in a randomized complete block design. In order to protect the plots from defoliation by Colorado potato beetle (Leptinotarsa decemlineata), the first generation of beetles was treated by chemigation with spinosad (Blackhawk Naturalyte; Dow Agro Science, LLC) at a rate of $69.9 \mathrm{~g}$ a.i. per ha. Spinosad was used for this study because of its low toxicity to aphids and other nontarget organisms (Thompson et al. 2000).

Aphid sampling. My. persicae and Ma. euphorbiae are the only two potato-colonizing aphid species known to occur in southern Idaho where this study was conducted (Alvarez et al. 2003). During each year of the study, sampling for these aphids was conducted weekly throughout the growing season, from plant emergence to vine kill. However, for analyses, weekly sample dates were converted to cumulative degree-days to facilitate between-year comparisons. To assess abundance and phenology, aphids were collected from the abaxial surface of six lower leaves from each of five randomly selected plants from the center row of each plot using a no. 2 sable hair paint brush. Aphids were placed in $95 \%$ ethyl alcohol and stored at $-20^{\circ} \mathrm{C}$ for later species-level identification and testing for virus (see below).

Virus incidence in aphids. A subsample $(50 \%$ of the total aphids collected each week during 2011 and 2012, and 20\% of the total aphids collected each week during 2013), separated by My. persicae and Ma. euphorbiae in each year, was tested with reverse transcription (RT)-PCR to estimate the proportion of PLRV-positive aphids. Aphids were tested either individually or in groups for larger aphid samples (see below). All winged aphids encountered were analyzed individually because of their relative rarity and their greater potential to transmit virus among multiple plants. Each aphid sample was placed in a $1.5-\mathrm{ml}$ microcentrifuge tube containing $70 \%$ ethyl alcohol. The ethyl alcohol then was removed and the sample allowed to dry for a short period before being homogenized using a PELLET PESTLE Cordless Motor (Kimble Chase, Vineland, NJ). Then, $100 \mu \mathrm{l}$ of DNase extraction buffer $(100 \mu \mathrm{l}$ buffer containing $10 \mu \mathrm{l}$ $0.1 \mathrm{M}$ Tris-HCL, $10 \mu \mathrm{l}$ of $2.5 \mathrm{mM} \mathrm{MgCl}_{2}, 20$ units/ml DNase [RNase free], and $80 \mu \mathrm{l}$ of ultrapure nuclease-free sterile water) was added to the aphid sample, which was homogenized again. Aphids collected from each plant were analyzed either individually (when fewer than five per plant were collected) or in pooled groups (when five or more per plant were collected). These groupings facilitated virus testing by eliminating the need to adjust buffer and reagent quantities on a continuous scale for each sample; instead, buffers and reagents were prepared only for samples of $1,2,5,10$, or 20 aphids. Within each sample, aphids were pooled into as few groups as possible (i.e., using the largest of these five possible groups in combination). For example, a plant with 48 aphids was partitioned into the following groups: 20, 20, 5, 2, and 1). The volume of the RNA extraction buffer used for each group was $100 \mu$ per five aphids (Singh et al. 1995). In the following steps of RNA extraction, reagent quantities were adjusted similarly. After homogenization, each sample was incubated at $37^{\circ} \mathrm{C}$ for $10 \mathrm{~min}$; then $10 \mu \mathrm{l}$ of $10 \%$ SDS and $5 \mu \mathrm{l}$ of proteinase $\mathrm{K}(10 \mathrm{mg} / \mathrm{ml})$ was added to the sample and incubated again at $65^{\circ} \mathrm{C}$ for $10 \mathrm{~min}$. Next, $100 \mu \mathrm{l}$ of water-saturated phenol was added to the sample, mixed vigorously by vortex, and spun down at $12,000 \mathrm{rpm}\left(4^{\circ} \mathrm{C}\right)$ for $10 \mathrm{~min}$. The lower-phase phenol was discarded and the supernatant was transferred into a new $1.5 \mathrm{ml}$ microcentrifuge tube, into which $100 \mu \mathrm{l}$ of chloroform-isoamyl alcohol solution (24:1) was added. The sample was mixed vigorously by vortex and centrifuged at $12,000 \mathrm{rpm}\left(4^{\circ} \mathrm{C}\right)$ for $10 \mathrm{~min}$. The resulting supernatant was removed and transferred to a new $1.5 \mathrm{ml}$ microcentrifuge tube containing $250 \mu \mathrm{l}$ chilled ethyl alcohol (95\%), $10 \mu \mathrm{l} 3 \mathrm{M}$ sodium acetate ( $\mathrm{pH} 5.5)$, and $1 \mu \mathrm{l}$ glycogen $(20 \mathrm{mg} / \mathrm{ml}$; RNA grade, Thermo Fisher Scientific, Waltham, MA, U.S.A.). The solution was mixed by vortex and allowed to precipitate overnight at $-20^{\circ} \mathrm{C}$. The RNA was spun down at $13,000 \mathrm{rpm}\left(4^{\circ} \mathrm{C}\right)$ for $30 \mathrm{~min}$; the resulting pellet was washed with $70 \%$ ethyl alcohol, and dried in a $37^{\circ} \mathrm{C}$ incubator for $10 \mathrm{~min}$. The dried RNA pellet was then suspended in $10 \mu \mathrm{l}$ of nuclease-free sterile water and stored at $-20^{\circ} \mathrm{C}$ before performing the PCR reaction.

Single step RT-PCR was performed using a multiplex primer as described by Singh et al. $(1995,1997)$. Reaction master mix was prepared using the BIO-RAD iTaq Universal Probes one-step kit (Bio-Rad, Hercules, CA, U.S.A.) and Rediload gel loading dye (Thermo Fisher Scientific). Each $20 \mu \mathrm{l}$ reaction mix contained $10 \mu \mathrm{l}$ of BIO-RAD PCR reaction mix $(0.5 \mathrm{mM}$ of each dNTP [dATP, dCTP, dGTP, dTTP], $\mathrm{Mg}^{++}$, antibody-mediated hot start Taq DNA polymerase, stabilizers), $4.5 \mu$ l of nuclease-free (DNase/RNase) water, $1 \mu l$ each of both the forward and reverse primer (PLRV-Singh F- 5'-CGCGCTAACAGAGTTCAGCC-3' and PLRV Singh R- 5' GCAATGGGGGTCCAACTCAT-3'), $2 \mu 1$ of Rediload gel loading dye, $0.5 \mu \mathrm{l}$ of iScript RT $(50 \times$ formulation of iScript RNase H+ MMLV reverse transcription), and $1 \mu l$ of sample RNA extract. The thermo-cycles for the PCR reaction consisted of $15 \mathrm{~min}$ at $50^{\circ} \mathrm{C}$ for cDNA synthesis, $5 \mathrm{~min}$ at $94^{\circ} \mathrm{C}$ for iScript reverse transcription inactivation, 30 cycles of $15 \mathrm{~s}$ at $94^{\circ} \mathrm{C}, 1 \mathrm{~min}$ at $58^{\circ} \mathrm{C}$, and $30 \mathrm{~s}$ at $72^{\circ} \mathrm{C}$ followed by a final extension at $72^{\circ} \mathrm{C}$ for $5 \mathrm{~min}$ and final storage of PCR product at $4^{\circ} \mathrm{C}$. After the PCR reaction, $15 \mu 1$ of the final amplified PCR product was analyzed by gel electrophoresis ( $2 \%$ agarose gel; Ultrapure Agarose, Invitrogen) by staining the product with ethidium bromide $(0.5 \mathrm{mg} / \mathrm{ml})$, and observing the gel under UV light (302 nm) in AlphaImager Mini (Cell Biosciences Inc., Santa Clara, CA, U.S.A.).

The resulting PCR product of the sample aphid RNA produced a diagnostic $336 \mathrm{bp}$ band in the agarose gel if PLRV was present. 
Aphid samples showing this band were scored as PLRV-positive. For samples containing multiple aphids from the same plant, all of them were considered positive if the sample showed the identifying band (Fig. 1). This was done because PLRV is transmitted in a persistent manner by aphids; thus, all apterous aphids collected from the same infected plant are likely to carry PLRV.

Virus incidence in potato plants. PLRV prevalence in plants in each plot was determined three times during the growing season. The sampling dates were 30 June, 30 July, and 29 August in 2011; 17 June, 17 July, and 16 August in 2012; and 5 June, 30 July, and 23 August for 2013. Each year, the final sample occurred shortly before vine kill. On each sample date, a composite leaflet sample was taken from the top, middle, and bottom portion of each of 10 randomly selected plants sampled from each of all three rows of each plot, totaling 30 plants per plot. Composite leaf samples were ground using an electric leaf press. Sap was collected and mixed with $0.5 \mathrm{ml}$ sample buffer $(1 \times$ phosphate-buffered saline [pH 7.4] containing $3.2 \mathrm{mM} \mathrm{Na}_{2} \mathrm{HPO}_{4}, 0.5 \mathrm{mM} \mathrm{KH}_{2} \mathrm{PO}_{4}, 1.3 \mathrm{mM} \mathrm{KCl}, 135 \mathrm{mM} \mathrm{NaCl}$, $0.05 \%$ Tween 20 , and $2 \mathrm{~g} /$ liter of powdered nonfat dry milk). To determine infection status in the plants, the samples were tested with double-antibody sandwich enzyme-linked immunosorbent assay (DAS-ELISA; [Clark and Adams 1977]) using polyclonal coating IgG and monoclonal conjugate (anti PLRV polyclonal and anti PLRV monoclonal conjugated with AP; BIOREBA, Reinach, Switzerland).

Statistical analysis. A generalized linear model was fitted to compare the mean aphid density among different varieties and among different sampling dates during each year, separately for the two aphid species collected. The main effects (year, date, and potato variety) and their interactions were evaluated using Proc GENMOD with a logit-link transformation in SAS version 9.3 (SAS Institute, Cary, NC). A Poisson response was used for assessing the mean aphid density among different varieties. Comparisons of aphid densities over time were facilitated by comparing a subset of dates across years rather than using all sample dates (Table 1). Cumulative degree days based on developmental thresholds of My. persicae (Ro and Long 1999; Ro et al. 1998) were calculated for each sampling date for each year, and statistical comparisons among treatments within each year were made for each of three sample dates over the season with similar degree days across all three years (Table 1). This approach focused comparisons on similar data points across years in which environmental conditions were similar for aphid population development. Comparisons of proportion of PLRV-infected plants among different potato varieties within and across years were made using PROCGENMOD with logit-link transformation assuming a binomial distribution. Correlations among aphid density, proportion of PLRV-positive aphids within samples, and proportion of PLRV infection in plants were examined using Spearman rank correlation (PROC-CORR) in SAS 9.3 .

\section{Results}

Aphid densities. My. persicae and Ma. euphorbiae were the only two potato colonizing species of aphids found in our samples during

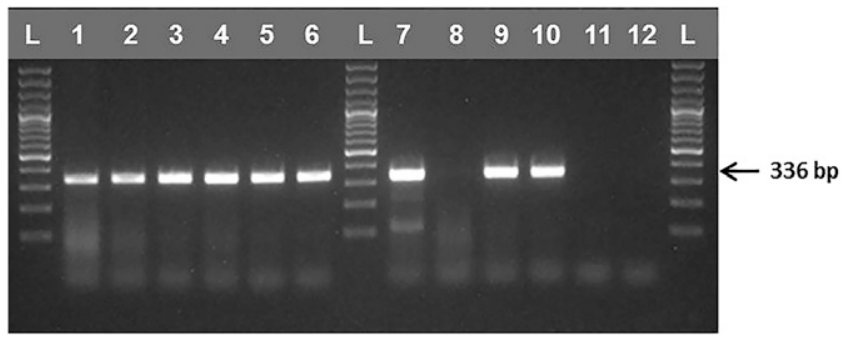

Fig. 1. Detection of PLRV in aphids by RT-PCR in ethidium bromide stained agarose gel (2\%). RT-PCR product of RNAs of lane 1 - single aphid; lane 2 - two aphids; lane 3 - five aphids; lane 4 - 10 aphids; lane 5 - 15 aphids; lane 6 - 20 aphids; Lane 7 PLRV-infected potato plant from field plot; lane 8 - PLRV-negative aphid; lane 9 positive control (plant); lane 10 - positive control (aphid); lane 11 - negative control (plant); lane 12 - negative control (aphid); lane L - 100 bp ladder. the course of the study. My. persicae represented at least $96.8 \%$ of total aphids collected each year, whereas Ma. euphorbiae represented $3.2,1.7$, and $0.05 \%$ of total aphid samples for 2011, 2012, and 2013, respectively. Mean $M y$. persicae density differed significantly among sampling dates within years, but densities did not differ significantly among varieties for any year (Table 2, Fig. 2). Aphid densities at similar cumulative degree-days and within each variety did not differ significantly among varieties, years, or their interactions (Tables 1 and 2, Fig. 2).

Due to the low numbers of Ma. euphorbiae collected (35 out of 1,076 total aphids, 32 out of 1,882, and 62 out of 129,266 for 2011,2012 , and 2013, respectively), statistical analyses were possible only for a few sample dates. However, because Ma. euphorbiae were not present in all compared sample dates across all years, statistical comparison of Ma. euphorbiae densities among years was not possible. Ma. euphorbiae density peaked around 550 to 950 cumulative degree-days in all three years; this also occurred for My. persicae in 2012, but in 2011 and 2013, My. persicae density peaked at around 750 to 1,150 cumulative degree-days (Figs. 2 and 3).

Relationships among aphids, virus incidence, and disease incidence. Although Ma. euphorbiae abundance was low, 5.7, 9.3, and $9.7 \%$ of Ma. euphorbiae tested PLRV positive in 2011, 2012, and 2013, respectively, while for My. persicae 10.3, 5.2, and 56.8\% tested PLRV positive. Across all years and varieties, PLRV prevalence in plants sampled was ca. $25 \%$ (Fig. 4). The total number of aphids (including PLRV-positive and PLRV-negative aphids) and the total number of aphids positive for PRLV was positively correlated with PLRV prevalence across all three varieties. The total number of aphids positive for PLRV was positively correlated with PLRV prevalence in Ranger Russet and Russet Norkotah, but not in Russet Burbank (Table 3).

PLRV infection in the three potato varieties. PLRV incidence in potato did not differ significantly among the three potato varieties pooled across years (Table 4, Fig. 4). PLRV prevalence differed significantly among years, across all three varieties, with greater incidence in $2013(44.7 \%)$ than in 2011 (17.5\%) and 2012 (13.1\%); 2011 and 2012 did not differ significantly from one another (Fig. 4). PLRV incidence differed significantly among sampling dates within each year, and among all years, for all varieties. In each

Table 1. Degree-days used for statistical analyses for each sample point during each year

\begin{tabular}{lccc}
\hline Year & 1st sampling date & 2nd sampling date & 3rd sampling date \\
\hline 2011 & 683 & 1,030 & 1,266 \\
2012 & 561 & 1,099 & 1,232 \\
2013 & 611 & 982 & 1,288 \\
\hline
\end{tabular}

Table 2. Comparison of green peach aphid densities among three potato varieties on three different sampling dates (based on degree days) within and across three years

\begin{tabular}{lccc}
\hline Variable $^{\mathbf{z}}$ & df & $\boldsymbol{\chi 2}$ & Pr $>\boldsymbol{\chi 2}^{\mathbf{2}}$ \\
\hline Year & 2 & 18.0 & $<0.0001$ \\
Variety & 2 & 0.5 & 0.769 \\
Date & 2 & 29.7 & $<0.0001$ \\
Date*Variety & 4 & 0.3 & 0.990 \\
Year*Date & 4 & 33.7 & $<0.0001$ \\
Year*Variety & 4 & 0.6 & 0.961 \\
Year*Date*Variety & 8 & 1.5 & 0.992 \\
\hline
\end{tabular}

${ }^{\mathrm{z}}$ Myzus persicae densities were compared among three potato varieties Russet Burbank, Russet Norkotah, and Ranger Russet in 2011, 2012, and 2013. Cumulative degree days were calculated for each sampling date for each year, and statistical comparisons among treatments within each year were made for three sample dates over the season with similar degree days across all three years. Differences in least square means of aphid density were compared using PROC GENMOD (assuming Poisson distribution) 
year, the incidence was highest during the third sampling date, followed by the second and first dates (Table 5).

\section{Discussion}

Despite considerable differences in overall aphid abundance among years, all three potato varieties in this study showed similar patterns of aphid colonization across years. All three potato varieties also showed similar relationships between PLRV incidence in plants and total aphid abundance, or proportion of PLRV-positive aphids. Thus, our results suggest that the three major varieties of potato grown in the northwestern U.S. are at similar risk of PLRV infection and aphid colonization. The predominant potato varieties in this region (Russet Burbank, Russet Norkotah, and Ranger Russet) all are susceptible to PLRV infection and may exhibit varying levels of virus prevalence $(83,67$, and $69 \%$ mean infection percentage in Russet Burbank, Russet Norkotah, and Ranger Russet, respectively, in a replicated field evaluation from 2000-12) (J. L. Whitworth, data not shown). However, aphid colonization patterns in these varieties had not been documented prior to the current study. We found that aphid colonization by My. persicae and Ma. euphorbiae did not differ among these three varieties, although differences in colonization by My. persicae (Davis et al. 2007) and other aphid species (Corsini and Brown 2001; Corsini et al. 1994) have been reported for other potato varieties.

Several studies have documented a host/vector manipulation phenomenon by plant viruses in diverse pathosystems (Bosque-Pérez and Eigenbrode 2011; Ingwell et al. 2012; Mauck et al. 2010; Moreno-Delafuente et al. 2013; Shrestha et al. 2012), including in the PLRV/aphid pathosystem (Eigenbrode et al. 2002; Rajabaskar et al. 2013a, b, 2014; Werner et al. 2009). Aphid arrestment and colonization is influenced, and often increased, by the altered chemical

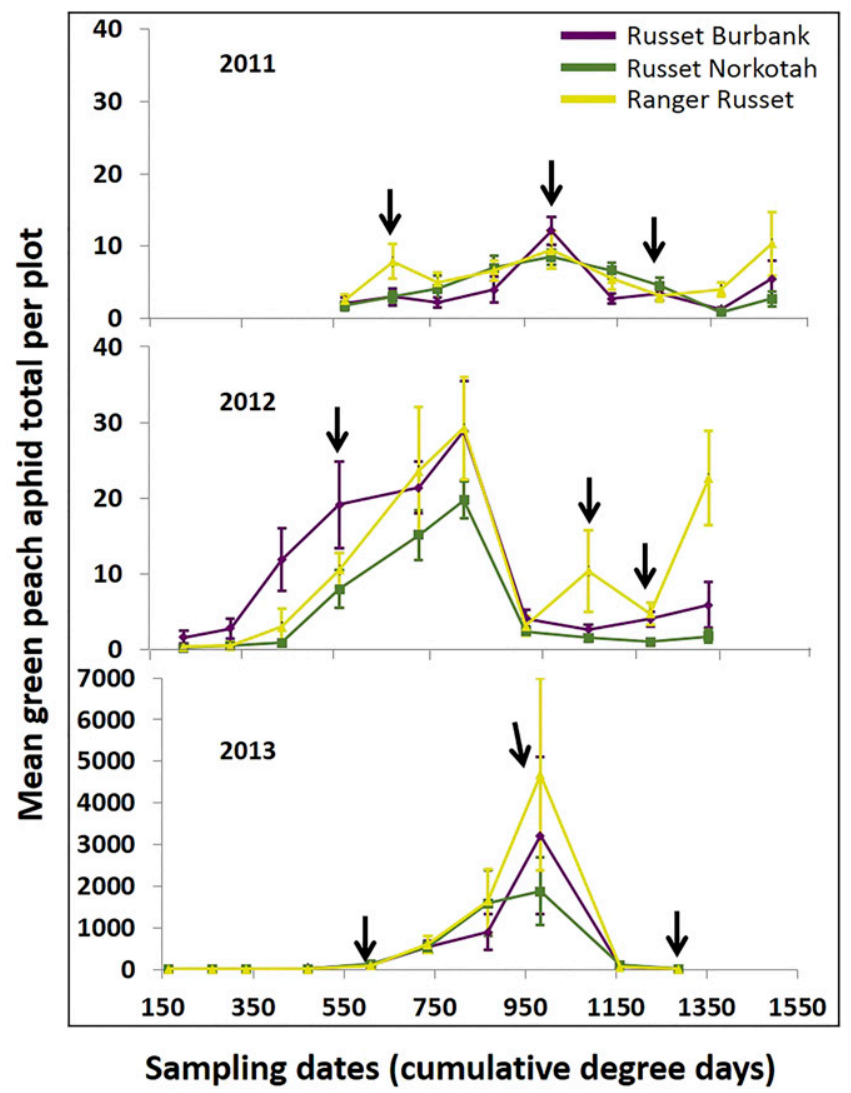

Fig. 2. Mean Myzus persicae densities on Russet Burbank, Russet Norkotah, and Ranger Russet in 2011, 2012, and 2013. Samples were taken weekly, but are reported here as a function of cumulative degree days on each sample date. Statistical comparisons among treatments within each year were made for three sample dates with similar degree days across all three years (indicated by arrows). Error bars represent SEM; $n=8$. Note the different $y$-axis scales among years. profile and physical appearance in different potato varieties and in alternative weed hosts that result from PLRV infection (DiFonzo et al. 1994; Nauen and Denholm 2005; Ragsdale et al. 2001; Rajabaskar et al. 2013b, c; Srinivasan et al. 2008). The similar patterns of aphid colonization that we observed suggest that all three potato varieties could exhibit similar volatile profiles and physical appearances, putting all three varieties at a similar risk not only for PLRV infection but also for becoming potential inoculum sources. Additional studies are required to examine these interactions.

PLRV disease dynamics are complex due to the persistent and circulative manner in which aphids acquire and transmit the virus as

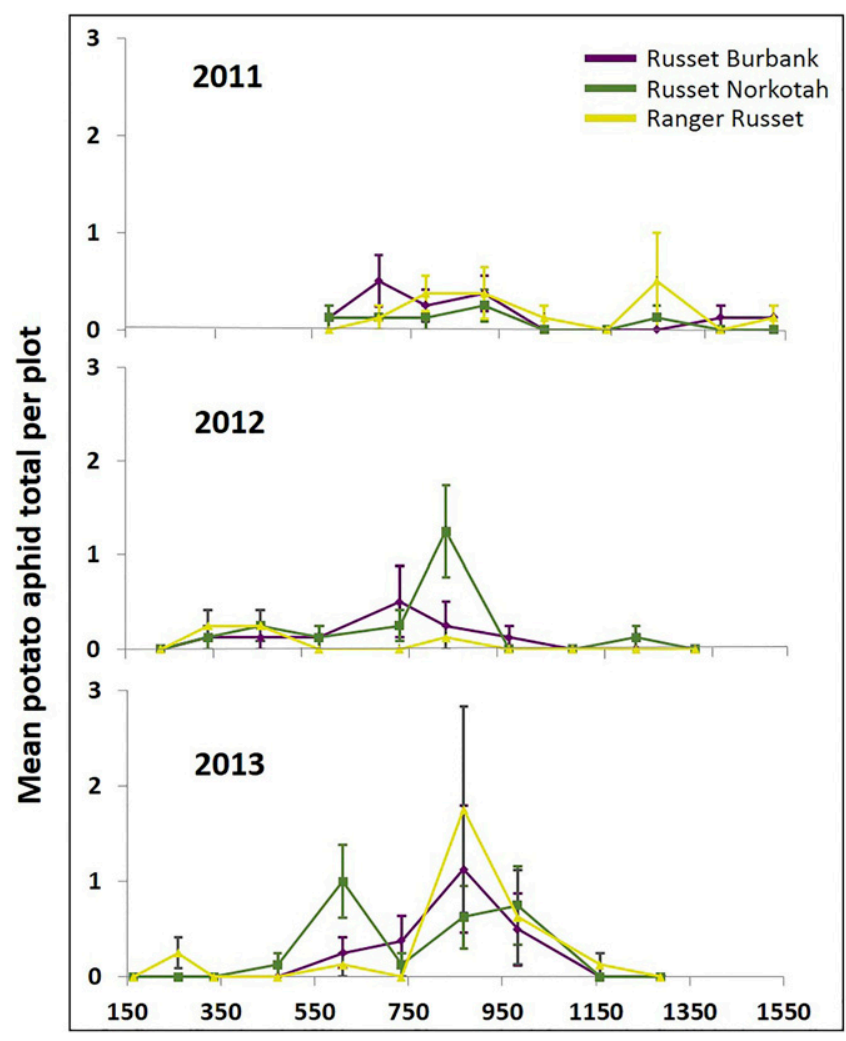

Sampling dates (cumulative degree days)

Fig. 3. Mean Macrosiphum euphorbiae densities on Russet Burbank, Russet Norkotah, and Ranger Russet across different sampling dates in 2011, 2012, and 2013. Samples were taken weekly, but are reported here as a function of cumulative degree days on the sample date. Statistical comparisons were not possible due to low number of Ma. euphorbiae captured. Error bars represent SEM; $n=8$.

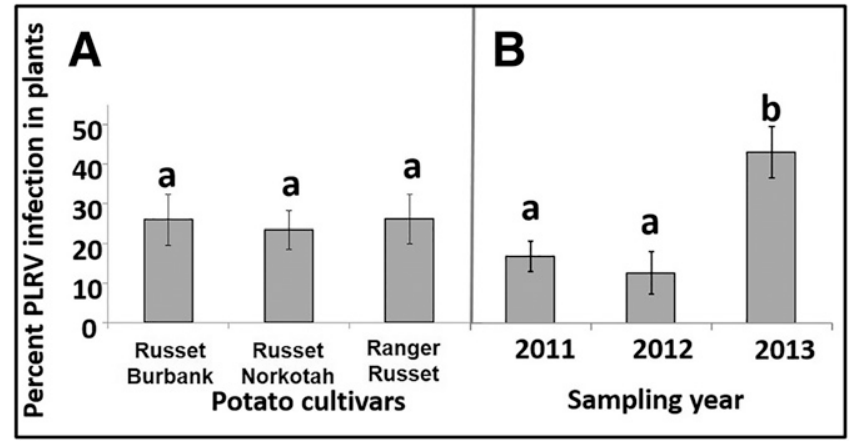

Fig. 4. PLRV incidence in potato (percent infection) on Russet Burbank, Russet Norkotah, and Ranger Russet) (A) and overall among 2011, 2012, and 2013 (B). Means within each group that share the same letter are not significantly different. Error bars represent SEM; $n=3$. 
well as the presence of alternative host plants for the virus and aphids (Gray and Banerjee 1999; Gray and Gildow 2003; Reavy and Mayo 2002; Srinivasan and Alvarez 2008; Srinivasan et al. 2013; Thomas et al. 1997; Zhu et al. 2006). The positive correlation between abundance of PLRV-positive aphids and proportion of PLRV-infected plants of Russet Norkotah and Ranger Russet suggest that PLRVpositive aphids might prefer to land on and colonize these varieties. Our data also suggest that aphids might have preferred to land on Russet Burbank and Russet Norkotah early in the season given that more viruliferous aphids were detected early in the season on these two varieties compared with Ranger Russet and Russet Norkotah later in the season (data not shown). Molecular monitoring for PLRV incidence in field-collected aphids (Singh 1999; Singh et al. 1996, 1997) early in the season may be useful in detecting initial PLRV inoculum levels. The present study showed that aphid abundance was positively correlated with PLRV incidence in plants, which is similar to findings from Flanders et al. (1991). Thus, it might not be necessary to test every aphid to predict inoculum level; rather, monitoring

Table 3. Correlation between PLRV infection percent and either total aphid number or number of PLRV-positive aphids in different potato varieties

\begin{tabular}{lcc}
\hline & \multicolumn{2}{c}{ Spearman correlation coefficient (and $\boldsymbol{P}$ value) } \\
\cline { 2 - 3 } Variety & $\begin{array}{c}\text { Total aphid } \\
\text { number } \times \text { infection } \\
\text { percent }^{\mathbf{y}}\end{array}$ & $\begin{array}{c}\text { PLRV-positive aphid } \\
\text { number }^{\mathbf{z}} \times \text { infection } \\
\text { percent }^{\mathbf{y}}\end{array}$ \\
\hline Russet Burbank & $0.766(0.027)$ & $0.596(0.119)$ \\
Russet Norkotah & $0.764(0.027)$ & $0.820(0.013)$ \\
Ranger Russet & $0.766(0.026)$ & $0.873(0.005)$ \\
\hline
\end{tabular}

y Because Macrosiphum euphorbiae abundance was very low relative to Myzus persicae, both species were counted together for correlation analyses. ${ }^{\mathrm{z}}$ PLRV-positive aphids were estimated by RT-PCR from the field-collected aphids, again combining Ma. euphorbiae and My. persicae. PLRV infection status in the plants was determined by DAS-ELISA.

Table 4. Comparison of PLRV incidence in three different potato varieties across years 2011, 2012, and 2013

\begin{tabular}{llccc}
\hline Variety $^{\mathbf{z}}$ & Variety compared with & df & $\boldsymbol{\chi 2}^{\mathbf{2}}$ & Pr $>\boldsymbol{\chi \mathbf { ~ }}^{\mathbf{2}}$ \\
\hline Russet Burbank & Russet Norkotah & 1 & 0.5 & 0.497 \\
Russet Burbank & Ranger Russet & 1 & 0.8 & 0.388 \\
Russet Norkotah & Ranger Russet & 1 & 0.04 & 0.838 \\
\hline
\end{tabular}

${ }^{\mathrm{z}}$ Composite leaf samples were collected from field plots and assayed with DAS-ELISA. Differences in least square means of percent PLRV infection in different potato varieties were compared pairwise using PROC GENMOD (assuming binomial distribution).

Table 5. PLRV incidence in three different potato varieties in the years 2011, 2012, and 2013 over three sample dates throughout the potato-growing season

\begin{tabular}{llccc}
\hline \multirow{2}{*}{ Year } & & \multicolumn{3}{c}{ Infection percent $^{\mathbf{z}}$} \\
\cline { 3 - 5 } 2011 & Rusiety & 1st sampling & 2nd sampling & 3rd sampling \\
& Russet Norkotah & $0 \mathrm{a}$ & $10.0 \mathrm{~b}$ & $22.5 \mathrm{c}$ \\
\multirow{4}{*}{2012} & Ranger Russet & $0 \mathrm{a}$ & $5.0 \mathrm{~b}$ & $15.0 \mathrm{c}$ \\
& Russet Burbank & $0 \mathrm{a}$ & $7.5 \mathrm{~b}$ & $15.0 \mathrm{c}$ \\
& Russet Norkotah & $0 \mathrm{a}$ & $7.5 \mathrm{~b}$ & $15.3 \mathrm{c}$ \\
\multirow{2}{*}{2013} & Ranger Russet & $0 \mathrm{a}$ & $2.5 \mathrm{~b}$ & $12.5 \mathrm{c}$ \\
& Russet Burbank & $0 \mathrm{a}$ & $13.8 \mathrm{~b}$ & $42.5 \mathrm{c}$ \\
& Russet Norkotah & $0 \mathrm{a}$ & $14.2 \mathrm{~b}$ & $41.3 \mathrm{c}$ \\
& Ranger Russet & $0 \mathrm{a}$ & $15.4 \mathrm{~b}$ & $50.4 \mathrm{c}$ \\
\hline
\end{tabular}

${ }^{\mathrm{z}}$ Composite leaf samples were collected from field plots on three sampling dates in each year-30 June, 30 July, and 29 August in 2011; 17 June, 17 July, and 16 August in 2012; 5 June, 30 July, and 23 August for 2013-and assayed with DAS-ELISA. Statistical analysis was carried out separately for each year. Mean infection percentages within each year that share the same letter are not significantly different. total aphid abundance and testing a subsample of aphids for presence or absence of virus may be useful to assess risk of virus infection. In the present study, variation in PLRV incidence among years was observed, which may be related to different inoculum pressure among years. This variation of PLRV inoculum pressure among years could be due to planting of PLRV-infected seed tubers, improper sanitation practices, presence of volunteer crops, presence of PLRV-infested weed hosts, and/or infestation of viruliferous aphids early in the season in certain years.

Although potato growers generally use at-plant insecticide applications (before aphid pressure is evident) as a foundation for the management of aphid-transmitted viruses, growers might be able to reduce management costs by applying management tools only when PLRV-positive aphids are found in a field. Such an approach would require investigation into the PLRV inoculum threshold that can result in economic loss for different potato varieties, in both commercial and seed production. A high PLRV inoculum with low aphid numbers might be more destructive than vice versa. Therefore, a monitoring system (aphid trapping and diagnostic tests on those aphids) should be developed to determine the proportion of PLRV-positive aphids among spring migrants. A subsample of the colonizing aphids also should be tested on a regular basis to estimate the risk of secondary spread. A combination of management practices may help reduce PLRV spread in commercial and seed growing areas (Davis and Radcliffe 2008; Robert et al. 2000; Vučetić et al. 2013).

Widespread use of certified virus-free seed tubers and application of neonicotinoid insecticides by potato growers have dramatically reduced PLRV in the northwestern U.S. (Halterman et al. 2012). However, PLRV has potential to further constrain potato production if aphids develop resistance to neonicotinoid insecticides (Bass et al. 2011, 2014; Beckingham et al. 2013; Fray et al. 2014; Puinean et al. 2010). The present study was conducted adjacent to fields that were inoculated with PLRV and into which aphids had been released. Thus, aphid and virus pressure were relatively high, which may represent the potential for aphid and disease pressure where insecticide resistance occurs.

Jones (2014) and Jones et al. (2010) advocated the development of new detection technology, improved information systems, and disease modeling to predict viral outbreaks. The present study has offered some potential disease monitoring approaches and risk mitigation strategies that can be incorporated into potato production systems. Molecular detection technology can enhance earlier detection of virus in the aphids; thus, the primary inoculum from spring migrants can be detected and potentially minimized. Weekly trapping and counting of aphids and testing a proportion of them for the presence of virus can be considered for developing a disease progression model. Furthermore, as spring aphids migrate from primary hosts to potato, the capture and testing of spring migrants with PCR might offer an estimate of the potential inoculum in aphid populations within a region. The three widely grown varieties tested in this study are highly susceptible to PLRV; thus, the ongoing efforts of potato breeding programs to develop PLRV-resistant varieties also will help mitigate losses from this virus in the future.

\section{Acknowledgments}

We thank Hanu R. Pappu for providing valuable suggestions for this study and William Price for advice on statistical analysis. We also thank Darren Hall and Ying Wu for providing PLRV checks for PCR analysis. Funding for this study was provided by USDA-RAMP grant \# 2009-031. We gratefully acknowledge the excellent technical assistance from Aretta Workman, Laura Park, LiAnna M. Good, Alyssa Ray Buffi, and Dan Henningsen. This is a publication of the Idaho Agricultural Experiment Station.

\section{Literature Cited}

Alvarez, J. M., and Srinivasan, R. 2005. Evaluation of hairy nightshade as an inoculum source for aphid-mediated transmission of potato leafroll virus. J. Econ. Entomol. 98:1101-1108.

Alvarez, J. M., Stoltz, R., Baird, C. I., and Sandvol, L. 2003. Potato insects and their management. Pages 204-239 in: Potato Production Systems. J. C. Stark and S. I. Love, eds. University of Idaho Agricultural Communication, Moscow, ID. 
Bass, C., Puinean, A. M., Andrews, M., Cutler, P., Daniels, M., Elias, J., Paul, V. L., Crossthwaite, A. J., Denholm, I., Field, L. M., Foster, S. P., Lind, R., Williamson, M. S., and Slater, R. 2011. Mutation of a nicotinic acetylcholine receptor $\beta$ subunit is associated with resistance to neonicotinoid insecticides in the aphid Myzus persicae. BMC Neurosci. 12:51.

Bass, C., Puinean, A. M., Zimmer, C. T., Denholm, I., Field, L. M., Foster, S. P., Gutbrod, O., Nauen, R., Slater, R., and Williamson, M. S. 2014. The evolution of insecticide resistance in the peach potato aphid, Myzus persicae. Insect Biochem. Mol. Biol. 51:41-51.

Beckingham, C., Phillips, J., Gill, M., and Crossthwaite, A. J. 2013. Investigating nicotinic acetylcholine receptor expression in neonicotinoid resistant Myzus persicae FRC. Pestic. Biochem. Physiol. 107:293-298.

Bosque-Pérez, N. A., and Eigenbrode, S. D. 2011. The influence of virus-induced changes in plants on aphid vectors: Insights from luteovirus pathosystems. Virus Res. 159:201-205.

Clark, M. F., and Adams, A. N. 1977. Characteristics of the microplate method of enzyme-linked immunosorbent assay for the detection of plant viruses. J. Gen. Virol. 34:475-483.

Corsini, D. L., and Brown, C. R. 2001. Important potato cultivars. Pages 39-52 in: Virus and Virus-like Diseases of Potatoes and Production of Seed-Potatoes. G. Loebenstein, P. H. Berger, A. A. Brunt, and R. H. Lawson, eds. Kluwar Academic Publishers, Dordrecht, the Netherlands.

Corsini, D. L., Pavek, J. J., Martin, M. W., and Brown, C. R. 1994. Potato germplasm with combined resistance to leafroll virus and viruses $\mathrm{X}$ and $\mathrm{Y}$. Am. Potato J. 71:377-385.

Davis, J. A., and Radcliffe, E. B. 2008. The importance of an invasive aphid species in vectoring a persistently transmitted potato virus: Aphis glycines is a vector of Potato leafroll virus. Plant Dis. 92:1515-1523.

Davis, J. A., Radcliffe, E. B., and Ragsdale, D. W. 2006. Effects of high and fluctuating temperatures on Myzus persicae (Hemiptera: Aphididae). Environ. Entomol. 35:1461-1468.

Davis, J. A., Radcliffe, E. B., and Ragsdale, D. W. 2007. Resistance to green peach aphid, Myzus persicae (Sulzer), and potato aphid, Macrosiphum euphorbiae (Thomas), in potato cultivars. Am. J. Potato Res. 84:259-269.

DiFonzo, C. D., Ragsdale, D. W., and Radcliffe, E. B. 1995. Potato leafroll virus spread in differentially resistant potato cultivars under varying aphid densities. Am. Potato J. 72:119-132.

DiFonzo, C. D., Ragsdale, D. W., Radcliffe, E. B., and Bantarri, E. E. 1994. Susceptibility to Potato leafroll virus in potato: Effects of cultivar, plant age at inoculation, and inoculation pressure on tuber infection. Plant Dis. 78: 1173-1177.

Douglas, D. R., and Pavek, J. J. 1972. Net necrosis of potato tubers associated with primary, secondary, and tertiary infection of leafroll. Am. Potato J. 49:330-333.

Eigenbrode, S. D., Ding, H., Shiel, P., and Berger, P. H. 2002. Volatiles from potato plants infected with Potato leafroll virus attract and arrest the virus vector, Myzus persicae (Homoptera: Aphididae). Proc. Biol. Sci. 269: 455-460.

Flanders, K. L., Radcliffe, E. B., and Ragsdale, D. W. 1991. Potato leafroll virus spread in relation to densities of green peach aphid (Homoptera, Aphididae) implications for management thresholds for Minnesota seed potatoes. J. Econ. Entomol. 84:1028-1036.

Flis, B., Syller, J., Wasilewicz-Flis, W., and Zimnoch-Guzowska, E. 2005. Interactions between Potato leafroll virus and potato plants and their implications for assessment of infection resistance. Am. J. Potato Res. 82: 411-417.

Foster, S. P., Cox, D., Oliphant, L., Mitchinson, S., and Denholm, I. 2008. Correlated responses to neonicotinoid insecticides in clones of the peachpotato aphid, Myzus persicae (Hemiptera: Aphididae). Pest Manag. Sci. 64: 1111-1114.

Foster, S. P., Denholm, I., and Devonshire, A. L. 2000. The ups and downs of insecticide resistance in peach-potato aphids (Myzus persicae) in the UK. Crop Prot. 19:873-879.

Fray, L. M., Leather, S. R., Powell, G., Slater, R., Mcindoe, E., and Lind, R. J. 2014. Behavioural avoidance and enhanced dispersal in neonicotinoidresistant Myzus persicae (Sulzer). Pest Manag. Sci. 70:88-96.

Gray, S. M., and Banerjee, N. 1999. Mechanisms of arthropod transmission of plant and animal viruses. Microbiol. Mol. Biol. Rev. 63:128-148.

Gray, S. M., and Gildow, F. E. 2003. Luteovirus-aphid interactions. Annu. Rev. Phytopathol. 41:539-566.

Halbert, S. E., Castle, S. J., and Mowry, T. M. 1995. Do Myzus (Nectarosiphon) species other than $M$. persicae pose a threat to the Idaho potato crop? Am. Potato J. 72:85-97.

Halterman, D., Charkowski, A., Verchot, J., and Daami-Remadi, M. 2012. Potato, viruses, and seed certification in the USA to provide healthy propagated tubers. Pest Technol. 6:1-14.

Hanafi, A., Radcliffe, E. B., and Ragsdale, D. W. 1989. Spread and control of Potato leafroll virus in Minnesota. J. Econ. Entomol. 82:1201-1206.

Hanafi, A., Radcliffe, E. B., and Ragsdale, D. W. 1995. Spread and control of potato leafroll virus in the Souss Valley of Morocco. Crop Prot. 14:145-153.

Harrison, B. D. 1958. Ability of single aphids to transmit both avirulent and virulent strains of Potato leaf roll virus. Virology 6:278-286.

Hutchinson, P. J. S. 2014. Hairy nightshade critical interference period in potatoes. Weed Technol. 28:543-551.
Ingwell, L. L., Eigenbrode, S. D., and Bosque-Pérez, N. A. 2012. Plant viruses alter insect behavior to enhance their spread. Sci. Rep. 2:578.

Jones, R. A. C. 2014. Trends in plant virus epidemiology: Opportunities from new or improved technologies. Virus Res. 186:3-19.

Jones, R. A. C., Salam, M. U., Maling, T. J., Diggle, A. J., and Thackray, D. J. 2010. Principles of predicting plant virus disease epidemics. Annu. Rev. Phytopathol. 48:179-203.

Mauck, K. E., De Moraes, C. M., and Mescher, M. C. 2010. Deceptive chemical signals induced by a plant virus attract insect vectors to inferior hosts. Proc. Natl. Acad. Sci. USA 107:3600-3605.

Moreno-Delafuente, A., Garzo, E., Moreno, A., and Fereres, A. 2013. A plant virus manipulates the behavior of its whitefly vector to enhance its transmission efficiency and spread. PLoS One 8:e61543.

Mowry, T. M. 2001. Green peach aphid (Homoptera: Aphididae) action thresholds for controlling the spread of Potato leafroll virus in Idaho. J. Econ. Entomol. 94 1332-1339.

Mowry, T. M. 2005. Insecticidal reduction of Potato leafroll virus transmission by Myzus persicae. Ann. Appl. Biol. 146:81-88

NASS. 2013. Crop Production (September 2013). Available at: http://www.nass. usda.gov/Statistics_by_Subject/index.php?sector=CROPS

Nauen, R., and Denholm, I. 2005. Resistance of insect pests to neonicotinoid insecticides: Current status and future prospects. Arch. Insect Biochem. Physiol. 58:200-215.

Nault, L. R. 1997. Arthropod transmission of plant viruses: a new synthesis. Ann Entomol. Soc. Am. 90:521-541.

Puinean, A. M., Foster, S. P., Oliphant, L., Denholm, I., Field, L. M., Millar, N. S., Williamson, M. S., and Bass, C. 2010. Amplification of a cytochrome P450 gene is associated with resistance to neonicotinoid insecticides in the aphid Myzus persicae. PLoS Genet. 6:e1000999.

Radcliffe, E. B., and Ragsdale, D. W. 2002. Aphid-transmitted potato viruses: The importance of understanding vector biology. Am. J. Potato Res. 79:353-386.

Ragsdale, D., Radcliffe, E., and diFonzo, C. D. 2001. Epidemiology and field control of PVY and PLRV. Pages 237-270 in: Virus and Virus-like Diseases of Potatoes and Production of Seed-Potatoes. G. Loebenstein, P. H. Berger, A. A. Brunt, and R. H. Lawson, eds. Kluwar Academic Publishers, Dordrecht, the Netherlands.

Rajabaskar, D., Bosque-Pérez, N. A., and Eigenbrode, S. D. 2014. Preference by a virus vector for infected plants is reversed after virus acquisition. Virus Res. 186:32-37.

Rajabaskar, D., Ding, H., Wu, Y., and Eigenbrode, S. D. 2013a. Different reactions of potato varieties to infection by Potato leafroll virus, and associated responses by its vector, Myzus persicae (Sulzer). J. Chem. Ecol. 39:1027-1035.

Rajabaskar, D., Ding, H., Wu, Y., and Eigenbrode, S. D. 2013b. Behavioral responses of green peach aphid, Myzus persicae (Sulzer), to the volatile organic compound emissions from four potato varieties. Am. J. Potato Res. 90:171-178.

Rajabaskar, D., Wu, Y., Bosque-Pérez, N. A., and Eigenbrode, S. D. 2013c Dynamics of Myzus persicae arrestment by volatiles from Potato leafrol virus-infected potato plants during disease progression. Entomol. Exp. Appl. 148:172-181

Reavy, B., and Mayo, M. A. 2002. Persistent transmission of luteoviruses by aphids. Adv. Bot. Res. 36:21-46.

Ro, T. H., and Long, G. E. 1999. GPA-phenodynamics, a simulation model for the population dynamics and phenology of green peach aphid in potato: Formulation, validation, and analysis. Ecol. Modell. 119:197-209.

Ro, T. H., Long, G. E., and Toba, H. H. 1998. Predicting phenology of green peach aphid (Homoptera: Aphididae) using degree-days. Environ. Entomol. 27: 337-343.

Robert, Y., and Bourdin, D. 2001. Aphid transmission of potato viruses. Pages 195-225 in: Virus and Virus-like Diseases of Potatoes and Production of Seed-Potatoes. G. Loebenstein, P. H. Berger, A. A. Brunt, andR. H. Lawson, eds. Kluwar Academic Publishers, Dordrecht, the Netherlands.

Robert, Y., Woodford, J. A. T., and Ducray-Bourdin, D. G. 2000. Some epidemiological approaches to the control of aphid-borne virus diseases in seed potato crops in northern Europe. Virus Res. 71:33-47

Salazar, L. F. 1996. Potato Viruses and their Control. International Potato Center, Lima, Peru.

Shrestha, A., Srinivasan, R., Riley, D. G., and Culbreath, A. K. 2012. Direct and indirect effects of a thrips-transmitted Tospovirus on the preference and fitness of its vector, Frankliniella fusca. Entomol. Exp. Appl. 145:260-271.

Singh, R. P. 1999. A solvent-free, rapid and simple virus RNA-release method for Potato leafroll virus detection in aphids and plants by reverse transcription polymerase chain reaction. J. Virol. Methods 83:27-33.

Singh, R. P., Kurz, J., and Boiteau, G. 1996. Detection of stylet-borne and circulative potato viruses in aphids by duplex reverse transcription polymerase chain reaction. J. Virol. Methods 59:189-196.

Singh, R. P., Kurz, J., Boiteau, G., and Bernard, G. 1995. Detection of Potato leafroll virus in single aphids by the reverse transcription polymerase chain reaction and its potential epidemiological application. J. Virol. Methods 55: 133-143.

Singh, R. P., Kurz, J., Boiteau, G., and Moore, L. M. 1997. Potato leafroll virus detection by RT-PCR in field-collected aphids. Am. Potato J. 74:305-313. 
Smith, E. A., DiTommaso, A., Fuchs, M., Shelton, A. M., and Nault, B. A. 2012. Abundance of weed hosts as potential sources of onion and potato viruses in western New York. Crop Prot. 37:91-96.

Srinivasan, R., and Alvarez, J. M. 2008. Hairy nightshade as a potential Potato leafroll virus (Luteoviridae: Polerovirus) inoculum source in Pacific Northwest potato ecosystems. Phytopathol. 98:985-991.

Srinivasan, R., Alvarez, J. M., Bosque-Pérez, N. A., Eigenbrode, S. D., and Novy, R. G. 2008. Effect of an alternate weed host, hairy nightshade, Solanum sarrachoides, on the biology of the two most important Potato leafroll virus (Luteoviridae: Polerovirus) vectors, Myzus persicae and Macrosiphum euphorbiae (Aphididae: Homoptera). Environ. Entomol. 37: 592-600.

Srinivasan, R., Alvarez, J. M., and Cervantes, F. 2013. The effect of an alternate weed host, hairy nightshade, Solanum sarrachoides (Sendtner) on green peach aphid distribution and Potato leafroll virus incidence in potato fields of the Pacific Northwest. Crop Prot. 46:52-56.

Stark, J., and Love, S. I., eds. 2003. Potato Production Systems. University of Idaho Agricultural Communication, Moscow, ID.

Syller, J. 1996. Potato leafroll virus (PLRV): its transmission and control. Integr. Pest Manage. Rev. 1:217-227.

Tamada, T., Harrison, B. D., and Roberts, I. M. 1984. Variation among British isolates of Potato leafroll virus. Ann. Appl. Biol. 104:107-116.

Thomas, J. 1993. Alternative hosts and the epidemiology of Potato leafroll virus in Queensland. Aust. J. Agric. Res. 44:1905-1916.
Thomas, P. E., and Hassan, S. 2002. First report of twenty-two new hosts of Potato leaf roll virus. Plant Dis. 86:561.

Thomas, P. E., Pike, K. S., and Reed, G. L. 1997. Role of green peach aphid flights in the epidemiology of Potato leaf roll disease in the Columbia basin. Plant Dis. 81:1311-1316.

Thompson, G. D., Dutton, R., and Sparks, T. C. 2000. Spinosad - a case study: an example from a natural products discovery programme. Pest Manag. Sci. 56: 696-702.

van Toor, R. F., Foster, S. P., Anstead, J. A., Mitchinson, S., Fenton, B., and Kasprowicz, L. 2008. Insecticide resistance and genetic composition of Myzus persicae (Hemiptera: Aphididae) on field potatoes in New Zealand. Crop Prot. 27:236-247.

Vučetić, A., Vukov, T., Jovičić, I., and Petrović-Obradović, O. 2013. Monitoring of aphid flight activities in seed potato crops in Serbia. ZooKeys 319:333-346.

Werner, B. J., Mowry, T. M., Bosque-Pérez, N. A., Ding, H., and Eigenbrode, S. D. 2009. Changes in green peach aphid responses to Potato leafroll virus-induced volatiles emitted during disease progression. Environ. Entomol. 38:1429-1438.

Woodford, J. A. T., Jolly, C. A., and Aveyard, C. S. 1995. Biological factors influencing the transmission of Potato leafroll virus by different aphid species. Potato Res. 38:133-141.

Zhu, M., Radcliffe, E. B., Ragsdale, D. W., MacRae, I. V., and Seeley, M. W. 2006. Low-level jet streams associated with spring aphid migration and current season spread of potato viruses in the U.S. Northern Great Plains. Agric. For. Meteorol. 138:192-202. 